\title{
Corpora lutea induced by gonadotrophin-releasing hormone treatment of anoestrous Welsh Mountain ewes: reduced sensitivity to luteinizing hormone in vivo and to chorionic gonadotrophin in vitro
}

\author{
T A Bramley ${ }^{1}$, D Stirling ${ }^{3}$, G S Menzies ${ }^{1}$ and D T Baird ${ }^{2}$ \\ ${ }^{1}$ Division of Reproductive \& Developmental Sciences and ${ }^{2}$ Contraceptive Development Network, The University \\ of Edinburgh Medical School, The Chancellor's Building, 49 Little France Crescent, Edinburgh EH16 4SB, \\ Scotland, UK, ${ }^{3}$ Department of Laboratory Medicine, New Royal Infirmary of Edinburgh, Edinburgh, Scotland, UK
}

Correspondence should be addressed to T A Bramley; Email: tbramley@staffmail.ed.ac.uk

\begin{abstract}
Seasonally anoestrous Welsh Mountain ewes received $250 \mathrm{ng}$ gonadotrophin-releasing hormone (GnRH) every $2 \mathrm{~h}$, with (Group 1; $n=13$ ) or without (Group 2; $n=14$ ) progesterone priming for $48 \mathrm{~h}$. Fourteen control ewes (Group 3) were studied during the luteal phase in the breeding season. Animals in Group $4(n=12)$ received progesterone priming followed by $250 \mathrm{ng} \mathrm{GnRH}$ at increasing frequency for $72 \mathrm{~h}$, while ewes in Group $5(n=13)$ were given three bolus injections of $30 \mu \mathrm{g}$ $\mathrm{GnRH}$ at 90-min intervals. All treatment regimens induced ovulation. However, only corpora lutea (CL) from ewes in Group 3 (breeding season) or Group 4 exhibited normal luteal function. Luteal luteinizing hormone (LH) receptor levels were significantly higher on day 12 than day 4 , and CL from groups with adequate $C L$ ( 3 and 4$)$ had significantly higher ${ }^{125}$ I-human chorionic gonadotrophin (hCG)-binding levels than the three groups with inadequate $\mathrm{CL}$ on day 12 . LH-binding affinity was unchanged. Exogenous ovine $\mathrm{LH}(10 \mu \mathrm{g})$ in vivo on days 3 or 11 after ovulation induced a pulse of progesterone in ewes with adequate CL: however, ewes in Groups 1, 2 and 5 showed no significant response. Basal progesterone secretion in vitro was significantly greater on day 4 than on day 12 . Maximal steroidogenic responses of adequate and inadequate CL to hCG and to dibutyryl cyclic-3', $5^{\prime}$-AMP were similar at both stages of the luteal phase. However, the $\mathrm{EC}_{50}$ for hCG on days 4 and 12 was 10 -fold lower for groups with an adequate $\mathrm{CL}(0.1 \mathrm{IU} \mathrm{hCG} / \mathrm{ml})$ than for inadequate-CL groups $(1 \mathrm{IU} \mathrm{hCG} / \mathrm{ml} ; P<0.05)$. Thus, in addition to the well-characterized premature sensitivity of $\mathrm{GnRH}$-induced inadequate $\mathrm{CL}$ to endometrial luteolysin, we have shown (1) a marked decrease in total number of cells in the $\mathrm{CL}$, a profound reduction in vascular surface area, and a decrease in mean large luteal cell volume (with no change in large luteal cell numbers), (2) decreased luteal LH receptor and progesterone content compared with adequate $\mathrm{CL}$ and (3) that $\mathrm{CL}$ that were becoming, or were destined to become, inadequate failed to respond to ovine LH in vivo and were 10-fold less sensitive to hCG in terms of luteal progesterone secretion in vitro.

Reproduction (2005) 129 61-73
\end{abstract}

\section{Introduction}

Inadequate luteal function contributes significantly to infertility (Hunter 1991, Garverick et al. 1992). Transient inadequate luteal function occurs naturally in sheep, for example, in early postpartum (Wright et al. 1983, 1984, Braden et al. 1989), at puberty and during the transition from anoestrus to the breeding season (Legan et al. 1985), and following ram-induced ovulation during anoestrus (Martin et al. 1986). Induction of ovulation in seasonally anoestrous ewes by the administration of luteinizing hormone $(\mathrm{LH})$ or gonadotrophin-releasing hormone $(\mathrm{GnRH}$;
Crighton et al. 1973) or GnRH agonist (McNeilly et al. $1981)$ generates inadequate corpora lutea $(\mathrm{CL})$, and such $\mathrm{CL}$ have been widely used as a model to study naturally occurring inadequate luteal function. The $\mathrm{CL}$ formed tend to be smaller and secrete less progesterone in vivo and in vitro than $\mathrm{CL}$ of the breeding season (McNeilly \& Land 1979, McNeilly et al. 1981). Increasing the frequency of LH (McNeilly et al. 1982) or GnRH pulses (Crighton et al. 1975, McLeod et al. 1982a, 1982b, Southee et al. 1988a, $1988 b)$ to mimic the final stages of follicular maturation during the breeding season increased ovulation rate during seasonal anoestrus but still gave rise frequently to 
abnormal CL. However, the incidence of adequate luteal phases during anoestrus was increased significantly by progesterone pretreatment prior to induction of ovulation with GnRH (McLeod et al. 1982b, Legan et al. 1985). Progesterone prolonged the period between $\mathrm{GnRH}$ injection and the onset of the LH surge (McLeod and Haresign 1984, Southee et al. 1988a), lengthening the final phase of follicular maturation, but had no effect on the onset, amplitude or duration of the LH surge (Wright et al. 1983, Legan et al. 1985).

A number of different mechanisms have been suggested to be responsible for the formation of inadequate luteal phases in sheep, including defective maturation of the preovulatory follicle (Keisler \& Keisler 1989, Hunter et al. 1986, White et al. 1987, Southee et al. 1988a, Khalid et al. 1997, Lund et al. 1999, Bartlewski et al. 2001), perhaps due to an inappropriate pattern of LH stimulation of the follicle prior to the LH surge (McLeod et al. 1982a, Wright et al. 1983, 1984), attenuation of the LH surge (Bartlewski et al. 2004), inadequate luteinization (Atkinson 1988, McNeilly et al. 1981, Hunter et al. 1988), inappropriate luteal support of the new CL (Hunter et al. 1988) and/or increased susceptibility to luteolytic stimuli (Hunter et al. 1989, Beard \& Hunter 1996) arising from the uterus (Southee et al. 1988b, Hu et al. 1991, though see Rahmanian and Murdoch 1987).

In order to distinguish factors that influence luteal function from other seasonal factors, we administered $\mathrm{GnRH}$ regimens that were predicted to give rise to adequate or inadequate $\mathrm{CL}$ to Welsh Mountain ewes during seasonal anoestrus, and assessed the incidence of ovulation, luteal morphology and hormonal responsiveness of the $\mathrm{CL}$ formed in vivo and in vitro at two stages of development.

\section{Materials and Methods}

\section{Materials}

All fine chemicals and reagents were purchased from Aldrich (Gillingham, Dorset, UK) or BDH (Poole, Dorset, UK). Radiolabelled $\left[1,2,6,7-{ }^{3} \mathrm{H}\right]$ progesterone $(100 \mathrm{Ci} /$ $\mathrm{mmol})$ and $\mathrm{Na}^{125} \mathrm{I}(100 \mathrm{mCi} / \mathrm{ml})$ were purchased from Amersham International. ${ }^{125}$ I-Labelled pregn-4-ene-3,20dione was purchased from Sigma Chemical Co. Highly purified human chorionic gonadotrophin (hCG; Profasi; $15000 \mathrm{IU} /$ vial) for radio-iodination was purchased from Serono (Welwyn Garden City, Herts, UK). hCG for the measurement of non-specific binding (Chorulon; $5000 \mathrm{U} /$ vial) was from Intervet Laboratories (Cambridge, UK). Antibodies for the assay of progesterone (S-361), prolactin (R2532), follicle-stimulating hormone (FSH) (M94) and LH (R29) were the generous gifts from Professor Alan McNeilly (MRC HRSU, Edinburgh, Scotland, UK). Normal rabbit serum and donkey anti-rabbit serum were purchased from the Scottish Antibody Production Unit, Carluke, Scotland, UK.

\section{In vivo studies}

Sixty-seven Welsh Mountain ewes of proven reproductive history were kept unmated over the preceding breeding season and maintained outdoors under natural lighting conditions at Dryden Field Laboratory, Roslin, Midlothian, Scotland Ewes were weighed, ranked for condition and allocated randomly to the appropriate groups. The study was performed in three parts, as follows.

First, during seasonal anoestrus (June) 13 ewes (Group 1) received $250 \mathrm{ng} \mathrm{GnRH}$ (Ayerst-Wyeth Pharmaceuticals, Maidenhead, Berks, UK) every $2 \mathrm{~h}$ for $48 \mathrm{~h}$ following a 12-day treatment with progesterone (three progesterone implants containing $375 \mathrm{mg}$ progesterone in a silicone elastomer matrix; Abbott Laboratories). Implants were placed in the axillary region and removed immediately after the second $\mathrm{GnRH}$ injection. Plasma progesterone concentrations at the end of the 12-day treatment were $3.9 \pm 0.4 \mathrm{ng} / \mathrm{ml}$ (mean \pm S.E.M.). Group 2 ewes $(n=14)$ received the same regimen of $\mathrm{GnRH}$ treatment as Group 1 , but without progesterone pretreatment (McLeod et al. 1982b). Animals were slaughtered on either day 4 or day 12 post-ovulation.

Secondly, the following March (late breeding season), the oestrous cycles of 14 ewes (Group 3) were synchronized (Chronogest progestagen pessaries; Intervet Laboratories). Ewes were left untreated for the first cycle. Following detection of oestrus of the second cycle with a vasectomized ram, blood samples were taken twice daily from the jugular vein until slaughter on day 4 or day 12 (oestrus $=$ day 0 ).

Finally, in mid-June (seasonal anoestrus), 26 ewes were weighed and allocated randomly to two groups. Twelve ewes (Group 4) were progestagen-treated for 7 days (Chronogest progestagen pessaries) and then received injections of $250 \mathrm{ng} \mathrm{GnRH}$ for $72 \mathrm{~h}$ at increasing frequencies (every $3 \mathrm{~h}$ for $24 \mathrm{~h}$, every $2 \mathrm{~h}$ for $24 \mathrm{~h}$ and finally every hour for a further $24 \mathrm{~h}$ ). Thirteen ewes (Group 5) received no progestagen treatment, but were given three bolus injections of $30 \mu \mathrm{g} \mathrm{GnRH}$ at 90-min intervals.

\section{Blood sampling}

Groups 1, 2, 4 and 5 were sampled every $15 \mathrm{~min}$ for $12 \mathrm{~h}$ before treatment started. Groups 1 and 2 were sampled every $2 \mathrm{~h}$ throughout the $48 \mathrm{~h}$ of $\mathrm{GnRH}$ injection, and every $4 \mathrm{~h}$ for a further $48 \mathrm{~h}$. In addition, 15 -min samples were collected for $6 \mathrm{~h}$ after the start of the 2-h GnRH injections. Ewes were then sampled twice daily until slaughter. Group 3 ewes were sampled twice daily until slaughter. Group 4 ewes were sampled before each injection of $\mathrm{GnRH}$ (i.e. with increasing frequency for $72 \mathrm{~h}$ ), every $4 \mathrm{~h}$ for a subsequent $24 \mathrm{~h}$, and then twice daily until slaughter. In addition, there was also a period of intense (15-min) sampling from the start of the $2 \mathrm{~h}$ injections. All blood samples at intervals of $4 \mathrm{~h}$ or less were taken via an indwelling venous catheter ( $3 \mathrm{ml}$ samples). Twice-daily samples $(7 \mathrm{ml})$ were collected by jugular venepuncture. 


\section{Responsiveness to $\mathrm{LH}$ in vivo}

To test the response to a physiological dose of ovine $\mathrm{LH}$ $(\mathrm{oLH})$ in vivo, ewes were sampled for a control period, then given a bolus intravenous injection of oLH $(10 \mu \mathrm{g}$ $\mathrm{NIH}-\mathrm{LH}-\mathrm{S} 15)$ on day 3 or day 11 . Blood samples were collected at $15 \mathrm{~min}$ intervals for a further $4 \mathrm{~h}$.

\section{In vitro studies}

\section{Tissue processing}

Ovaries were collected from ewes at slaughter on days 4 or 11 of the luteal phase, and transported to the laboratory on ice within an hour. CL were excised, trimmed free of fat and connective tissue, weighed, and divided into roughly equal portions for tissue incubations, receptor assays and morphological studies.

\section{Histological studies}

Wedge-shaped segments of luteal tissue (representing $20-25 \%$ of each $\mathrm{CL}$ ) were taken from five or six animals from each group (from ewes that had shown no premature fall in serum progesterone) and fixed by immersion in $2 \%$ glutaraldehyde/0.1 M cacodylate buffer, $\mathrm{pH} 7.4$, for $2 \mathrm{~h}$, then in $5 \%$ glutaraldehyde $/ 0.1 \mathrm{M}$ cacodylate buffer for a further $2 \mathrm{~h}$. Fixed tissue was sliced into $1 \mathrm{~mm}^{3}$ pieces with new razor blades, then 5-10 pieces were randomly selected and post-fixed in osmium tetroxide ( $2 \%)$ for $2 \mathrm{~h}$, dehydrated in alcohol and embedded in epon araldite. Semi-thin sections $(1 \mu \mathrm{m})$ were cut and stained with Toluidene Blue for morphometric analysis. Cell number and cell size were measured in five squares of a micrometer grid for four random separate fields of view for each section by defocusing the microscope and moving the stage along a predetermined track. For each $\mathrm{CL}$, a total of 100-200 cells was counted.

To estimate the surface area of vasculature per unit volume of tissue, the number of intercepts of the surface and a bar on an M42 (21-bar) grid (L4062 eyepiece graticule; Agar Aids, Agar Scientific, Stanstead, UK) were counted at random by defocusing the microscope and moving the stage along a predetermined track. Vascular surface area was calculated from the formula $S_{\mathrm{v}}=2 \times I / L$ where $I$ is the number of intercepts and $L$ is the total length of the grid bars, taking into account the magnification (Weibel 1989, Cruz-Orive \& Weibel 1990, Lecocq 1993).

Using a Tektronix (Thurlby Thandar Instruments, Huntingdon, Cambs, UK) image analyser, all nucleated cells with a diameter of $>15 \mu \mathrm{m}$ within a square of known size and section of known thickness were measured. Cells were only counted if their nucleus fell within or transected the upper and/or left side of the grid square. Perimeters of cells were traced and measured, areas of profiles estimated and mean cell volume calculated. The number of cells per unit volume of fixed tissue $\left(N_{v}\right)$ was estimated from the sum of all blocks using the formula $N_{v}=1 / \beta N_{\mathrm{a}}^{1.5} / V_{\mathrm{v}}^{0.5}$ where $N_{\mathrm{a}}$ is the number of cells measured, $V_{v}$ is the volume fraction of the cells (i.e. the combined area of all measured cells divided by the true area of the section studied) and $\beta$ is a correction factor based on nuclear shape $(\beta=1.382$ for luteal cells; Rodgers et al. 1984). The number of cells per CL was the product of this $N_{v}$ and the volume of the CL. Mean cell volume was calculated from the mean cell diameter of two measurements at right angles, assuming that luteal cells are spherical $\left(4 / 3 \pi r^{3}\right)$.

\section{Progesterone secretion in vitro}

Duplicate aliquots of minced tissue from each $\mathrm{CL}$ were incubated at $37^{\circ} \mathrm{C}$ in either $1 \mathrm{ml}$ M199 alone (Flow Laboratories, Irvine, Scotland) or M199 supplemented with hCG (Chorulon; $10^{-4}$ to $10^{2} \mathrm{IU} / \mathrm{ml}$ in 10 -fold increments) or $N^{6}, 2^{\prime} O$-dibutyryl cyclic-3', $5^{\prime}$-AMP (dbcAMP; $0.0625-0.5 \mathrm{mM}$ ), as described in the figure legends. After incubation, tubes were centrifuged (5000 $\mathrm{g}$ for $10 \mathrm{~min}$ ) and tissue pellets and media stored separately at $-20^{\circ} \mathrm{C}$. Tissue pellets were homogenized and assayed for protein (Lowry et al. 1951) to correct steroid secretion for differing amounts of tissue. Incubation media were assayed for progesterone by RIA (Scaramuzzi \& Baird 1977).

\section{Assays}

oLH was measured by RIA using the method of McNeilly et al. (1985). Assay sensitivity was $0.2 \mathrm{ng} / \mathrm{ml}$, and intraand inter-assay coefficients of variation were 5.2 and $12.1 \%$ respectively. Plasma $\mathrm{FSH}$ concentrations were measured using the RIA described by McNeilly et al. (1976). Assay sensitivity was $4 \mathrm{ng} / \mathrm{ml}$, and intra- and interassay coefficients of variation were 4.9 and $11.8 \%$ respectively. Prolactin was measured using the assay of McNeilly \& Andrews (1974). Assay sensitivity was $0.1 \mathrm{ng} / \mathrm{ml}$, and intra- and inter-assay coefficients of variation were 8.1 and $11.2 \%$ respectively.

Serum progesterone concentrations were measured in duplicate aliquots $(200 \mu \mathrm{l})$ of plasma samples following extraction with $2 \mathrm{ml}$ freshly distilled peroxide-free petroleum ether. After vortexing for $30 \mathrm{~min}$, samples were frozen in a dry ice/methanol bath, and the organic phase dried under nitrogen. Extraction efficiency was estimated by recovery of $\left[{ }^{3} \mathrm{H}\right]$ progesterone (1000 c.p.m.). Dried samples were reconstituted in $300 \mu \mathrm{l} 0.1 \%$ gelatin/PBS, diluted and radioimmunoassayed (Djahanbakhch et al. 1981) using ${ }^{125}$ I-labelled pregn-4-ene-3,20-dione tracer. Assay sensitivity was $0.1 \mathrm{ng} / \mathrm{ml}$, and intra- and inter-assay coefficients of variation were 7.2 and $10.9 \%$ respectively for five separate assays. Culture medium did not interfere with the assay, so progesterone content of media was measured without solvent extraction.

\section{Assay of occupied and unoccupied $L H$ receptors}

Unoccupied LH receptors were measured by specific binding of ${ }^{125}$ I-labelled hCG (Profasi; radio-iodinated to 
a specific binding activity of $35 \mathrm{Ci} / \mathrm{g}$ estimated by selfdisplacement assay) to aliquots $(10-100 \mu \mathrm{l})$ of ovine luteal homogenates as described previously (Bramley et al. 1987). Values of $B_{\max }$ and $K_{\mathrm{a}}$ for luteal $\mathrm{LH} / \mathrm{hCG}$ receptors were estimated from Scatchard plots constructed from triplicate measurements of specific binding at 8-10 concentrations (0.5-30 pM) of ${ }^{125}$ I-hCG (Bramley et al. 1987).

Preliminary experiments demonstrated that bound ${ }^{125}$ I-hCG was released with high efficiency following incubation on ice at pH 3.0 (Fig. 1A) for 5 min (Fig. 1B). Therefore occupied $\mathrm{LH}$ receptor levels were measured by dissociation of bound oLH from aliquots $(100 \mu \mathrm{l})$ of luteal homogenate with $100 \mu \mathrm{l}$ ice-cold $0.1 \mathrm{M}$ citrate buffer, $\mathrm{pH}$ 3.0. After $5 \mathrm{~min}, \mathrm{pH}$ was immediately restored to 7.4 by addition of $175 \mu \mathrm{l} 1 \mathrm{M}$ Tris $-\mathrm{HCl}, \mathrm{pH} 7.5$, tubes were centrifuged at $30000 \mathrm{~g}$ for $15 \mathrm{~min}$, and the oLH released
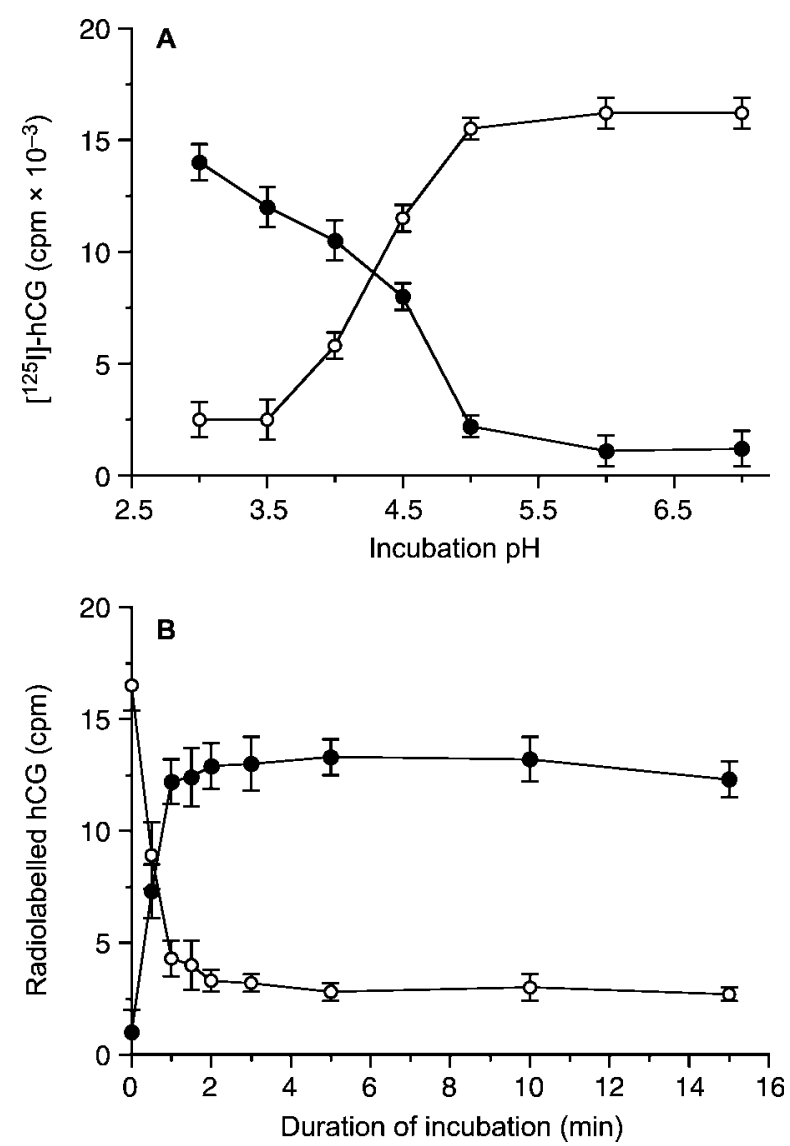

Figure 1 Dissociation of bound ${ }^{125}$ I-hCG from ovine luteal tissue. Triplicate aliquots $(500 \mu \mathrm{l})$ of mid-luteal ovine $\mathrm{CL}$ were incubated with 500000 c.p.m. ${ }^{125} \mathrm{I}$-hCG tracer (specific activity of binding, $35 \mathrm{Ci} / \mathrm{g}$ ) in $0.1 \% \mathrm{BSA} / \mathrm{Tris}-\mathrm{HCl}$ buffer, $\mathrm{pH} 7.4$, overnight at $20^{\circ} \mathrm{C}$. Bound hormone was recovered by centrifugation at $15000 \mathrm{~g}$ for $15 \mathrm{~min}$ and the pellet resuspended in BSA/Tris buffer. Triplicate aliquots $(100 \mu \mathrm{l})$ were then incubated in ice-cold $0.1 \mathrm{M}$ acetic acid/ sodium citrate buffer of the appropriate $\mathrm{pH}$ for $5 \mathrm{~min}(\mathrm{~A})$, or at $\mathrm{pH}$ 3.0 for the appropriate time (B). Tubes were then centrifuged at $30000 \mathrm{~g}$ for $30 \mathrm{~min}$, and the pellet (o) or supernatant (•) counted for ${ }^{125}$ I radioactivity. Points are means \pm S.E.M. from a single representative experiment in triplicate. Similar data were obtained in four less-complete experiments. was measured in aliquots of the supernatant by immunoassay. Receptor concentrations were adjusted for DNA content (Burton 1956) using calf thymus DNA as standard.

\section{Analysis of data}

Onset of the preovulatory LH surge was considered to have occurred when plasma $\mathrm{LH}$ levels exceeded $15 \mathrm{ng} / \mathrm{ml}$, provided that levels in two consecutive samples were greater than the mean of the previous two samples, and at least one of the peak samples exceeded the mean basal level by more than three times the coefficient of variation of the assay (Backstrom et al. 1982).

Luteal function was defined as adequate when plasma progesterone concentrations (1) rose within 4 days of the LH surge, (2) remained elevated for at least 8 days and (3) reached concentrations of $>1.5 \mathrm{ng} / \mathrm{ml}$ for at least 2 consecutive days (Hunter et al. 1986).

\section{Statistics}

The incidence of ovulation and adequacy of luteal function were compared between groups using the $\chi^{2}$ test or Fisher's exact test. Hormone profiles were compared using two-way analysis of variance with repeated measures, followed by Duncan's multiple-range test where appropriate. Morphometric parameters were compared between groups using Student's $t$ test.

\section{Results}

\section{Ovulation and luteal function}

The proportion of ewes in each treatment group that ovulated in response to $\mathrm{GnRH}$ treatment ranged from 5/13 to 9/13 (Table 1). The remaining animals showed no elevation in plasma progesterone, and no evidence of luteal structures at dissection. All ovulating ewes had only a single CL: there were no multiple ovulations. There were no statistically significant differences in the proportion of ewes ovulating between the groups. However, only ewes in Group 3 (breeding season; $n=13 / 13$ ) and Group 4 (progesterone pretreated with increasing $\mathrm{GnRH}$ frequency for $72 \mathrm{~h} ; n=10 / 12$ ) showed adequate luteal function. The interval between the last bolus GnRH injection and the onset of LH surge in Group 5 was only $1.5 \mathrm{~h}$, and the LH surge was significantly reduced and foreshortened (Table 1). However, there were no significant differences in duration or magnitude of the $\mathrm{LH}$ surge between Groups 1 and 4, although time to the onset of the $\mathrm{LH}$ surge was longer for Groups 3 and 4 compared with Group $2(P<0.02)$, but not Group 1 .

\section{Plasma gonadotrophin concentrations}

There were no significant differences in basal LH concentrations $(1.3 \pm 0.2 \mathrm{ng} / \mathrm{ml})$, LH pulse frequency $(1.7 \pm 0.5$ pulses $/ 12 \mathrm{~h})$ or $\mathrm{LH}$ pulse amplitude $(10.7 \pm 2.8 \mathrm{ng} / \mathrm{ml})$ 
Table 1 Pituitary and ovarian responses to GnRH injection. Ovulation was assessed by a rise in plasma progesterone concentrations and the presence of a CL or corpus albicans at slaughter. Data are means \pm S.E.M.

\begin{tabular}{|c|c|c|c|c|c|c|}
\hline Group & Treatment & $\begin{array}{c}\text { Proportion } \\
\text { ovulating }\end{array}$ & $\begin{array}{l}\text { Duration of } \\
\text { LH surge }(h)\end{array}$ & $\underset{(\mathrm{ng} / \mathrm{ml})}{\text { LH surge }}$ & $\begin{array}{l}\% \text { Adequate } \\
\text { luteal phases }\end{array}$ & $\begin{array}{l}\text { Interval between GnRH } \\
\text { injection and LH surge }(h)\end{array}$ \\
\hline 1 & $\begin{array}{l}250 \mathrm{ng} \mathrm{GnRH} \text { every } 2 \mathrm{~h} \text { for } 48 \mathrm{~h} \\
\text { Progesterone pretreated }\end{array}$ & $5 / 13$ & $16.6 \pm 2.3$ & $151 \pm 17$ & 0 & $37.2 \pm 3.0$ \\
\hline 2 & $\begin{array}{l}250 \mathrm{ng} \mathrm{GnRH} \text { every } 2 \mathrm{~h} \text { for } 48 \mathrm{~h} \\
\text { No progesterone pretreatment }\end{array}$ & $9 / 14$ & $14.1 \pm 3.7$ & $144 \pm 19$ & 0 & $22.0 \pm 8.5$ \\
\hline 3 & Breeding season & $13 / 13$ & $16.4 \pm 2.9$ & $137 \pm 20$ & 100 & $50.0 \pm 7.7^{b}$ \\
\hline 4 & $\begin{array}{l}250 \mathrm{ng} \text { for } 72 \mathrm{~h} \text { at increasing frequency } \\
\text { Progesterone pretreated }\end{array}$ & $10 / 12$ & $18.3 \pm 4.2$ & $176 \pm 23$ & 100 & $52.0 \pm 8.9^{b}$ \\
\hline 5 & $\begin{array}{l}30 \mu g \mathrm{GnRH} \times 3 \text { No progesterone } \\
\text { pretreatment }\end{array}$ & $9 / 13$ & $7.8 \pm 2.1^{\mathrm{a}}$ & $95 \pm 9^{a}$ & 0 & (1.5) \\
\hline
\end{tabular}

${ }^{\text {a }}$ Significantly different from other groups $(P<0.05)$.

${ }^{\mathrm{b}}$ Significantly different form Group $2(P<0.02)$.

between groups before the start of treatment, and no significant differences in $\mathrm{LH}$ pulse amplitude in response to $2 \mathrm{~h}$ GnRH injections for Groups 1, 2 and 4 (data not shown). Similarly, mean FSH levels before the start of treatment $(58 \pm 7 \mathrm{ng} / \mathrm{ml})$ and $\mathrm{FSH}$ response to $\mathrm{GnRH}$ (mean concentration, $83 \pm 9 \mathrm{ng} / \mathrm{ml}$ ) were similar in all groups $(P>0.05)$. There were no significant differences between treatment groups in prolactin concentrations $(118 \pm 27 \mathrm{ng} / \mathrm{ml})$ throughout the luteal phase. However, irrespective of treatment group, mean prolactin concentrations were significantly lower $(P<0.02)$ in ewes with short-lived luteal phases $(112 \pm 8 \mathrm{ng} / \mathrm{ml})$ compared with ewes in which CL survived until day $12(134 \pm 4 \mathrm{ng} / \mathrm{ml}$; $P<0.02)$

\section{Plasma progesterone concentrations}

Plasma progesterone concentrations of ewes that ovulated and were tracked up to day 12 are shown in Fig. 2A. Mean progesterone concentrations for treatment Groups 1, 2 and 5 showed no significant differences (until beyond day 10, when mean progesterone levels in Group 5 ewes fell).

\section{Response to $\mathrm{LH}$ stimulation in vivo}

Injection of oLH $(10 \mu \mathrm{g})$ generated a similar pulse of plasma LH for ewes in all treatment groups (mean pulse amplitude, $3.3 \pm 0.7 \mathrm{ng} / \mathrm{ml}$ ). During the breeding season (Group 3), the LH pulse was followed by a significant elevation in plasma progesterone concentrations on both day 3 (Fig. 3A) and day 11 (Fig. 3D). Similarly, ewes in Group 4 also showed a sharp rise in progesterone (Fig. 3B and $\mathrm{E}$ ). However, there was no significant plasma progesterone increase in response to $\mathrm{LH}$ injection in ewes from Groups 1, 2 and 5 on either day 3 (Fig. 3C) or (in the four ewes in which a CL was still present) on day 11 (Fig. 3F).

Some ewes with adequate (Fig. 4A and B) or inadequate $\mathrm{CL}$ (Fig. 4C and D) exhibited an endogenous $\mathrm{LH}$ pulse during the course of the $4 \mathrm{~h}$ sampling period. In ewes with adequate $\mathrm{CL}$, there was a significant increase in plasma progesterone in response to both an exogenous oLH and endogenous $\mathrm{LH}$ pulse on both day 3 (Fig. 4A)
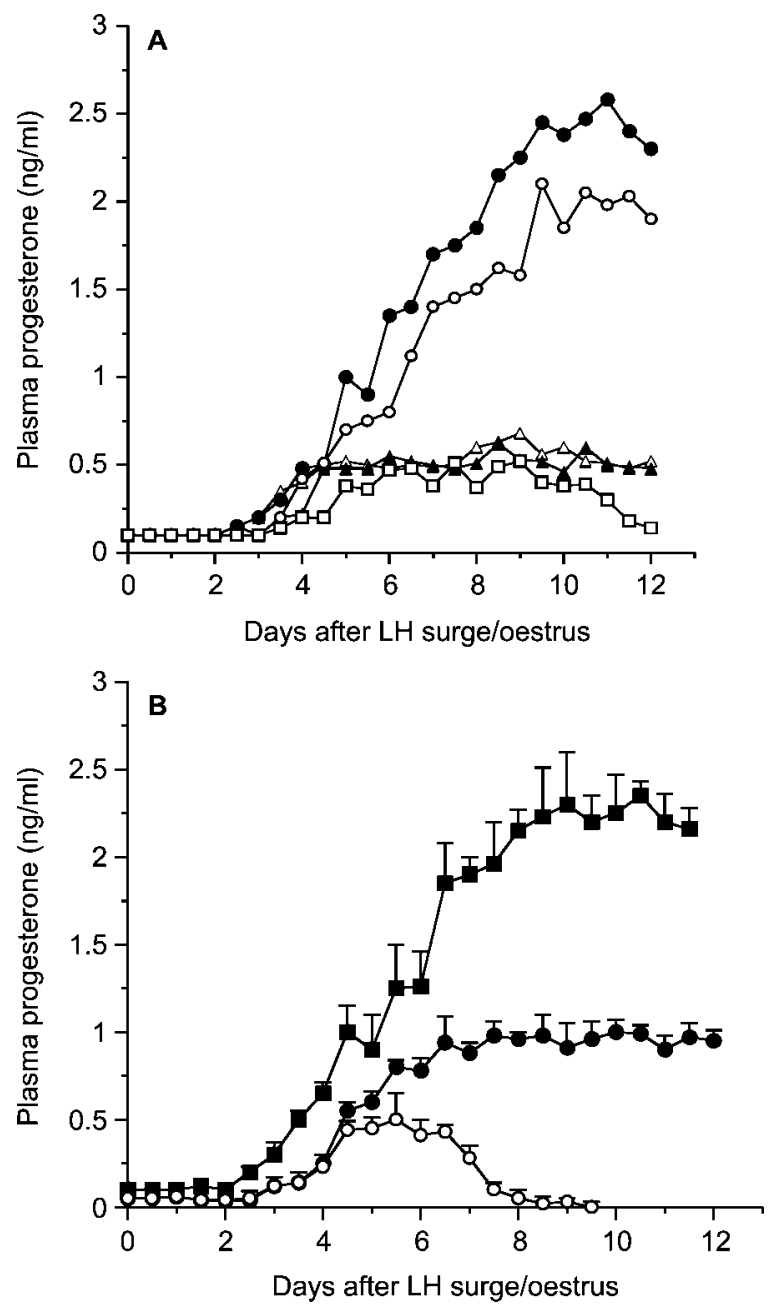

Figure 2 Luteal plasma progesterone levels in ewes from the different treatment groups. (A) Anoestrous ewes or ewes during the breeding season were treated as described in the Materials and Methods section and blood samples collected twice daily for 12 days. Plasma progesterone levels were measured by immunoassay. Symbols used: Group $1(\triangle ; n=5)$; Group $2(\Delta, n=9)$; Group $3(\bullet ; n=13)$; Group $4(\circ, n=10)$; Group $5(\square ; n=9)$. Points are means for all ewes in each treatment group. (B) Ewes during the breeding season (Group 3; $\mathbf{a} ; n=13$ ) or anoestrous ewes (from Groups 1 and 2) having a transient $(0 ; n=4)$ or a persistent $\mathrm{CL}(\bullet ; n=4)$ as assessed retrospectively. Points are means \pm S.E.M. 

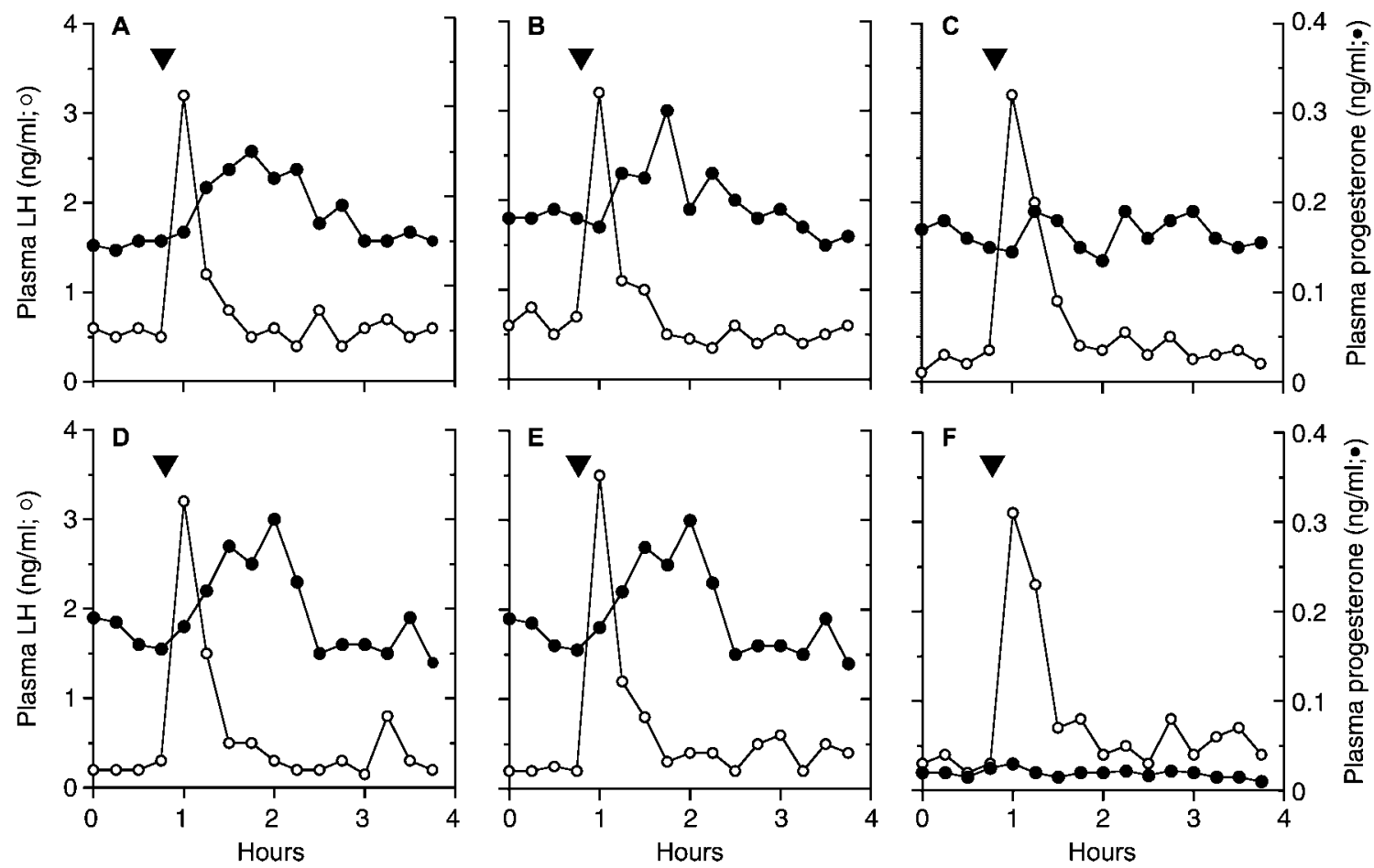

Figure 3 Plasma progesterone concentrations in response to oLH injection in vivo. Anoestrous ewes or breeding-season ewes were treated as described in the Materials and Methods section and injected with $10 \mu \mathrm{g}$ oLH (arrowhead) on either day 3 (A, C, E) or day 11 (B, D, F) of the luteal phase. Blood samples were collected every $15 \mathrm{~min}$ for $4 \mathrm{~h}$, and plasma levels of oLH (o) and progesterone (•) were measured by immunoassay. (A) Day 3, Group 3 (breeding season; $n=6$ ); (B) day 3, Group 4 (adequate CL; $n=5$ ); (C) day 3, Groups 1, 2 and 5 (inadequate CL; $n=10$ ); (D) day 11, Group 3 (breeding season; $n=7$ ); (E) day 11, Group 4 (adequate $\mathrm{CL} ; n=5$ ); (F) day 11, Groups 1, 2 and 5 (inadequate $\mathrm{CL}$; $n=13)$. Points are means for $4-8$ ewes per group.

and day 11 (Fig. 4B). In contrast, ewes in the inadequatetreatment groups (1,2 and 5) failed to respond to exogenous or endogenous oLH at either stage of the luteal phase (Fig. 4C and D).

\section{Characteristics of $C L$}

All groups showed a significant increase in luteal weight between days 4 and 12 (Table 2). CL from the breeding season were significantly heavier on days 4 and 12 than those induced by ovulation during anoestrus. Luteal progesterone content was significantly higher in breedingseason $\mathrm{CL}$ compared with the three inadequate $\mathrm{CL}$ groups. Intermediate luteal progesterone levels were observed in $\mathrm{CL}$ from Group 4 (adequate induced) ewes.

Unoccupied luteal LH receptor levels rose significantly between days 4 and 12 in all groups and were significantly higher in the two groups with adequate CL (Groups 3 and 4) on day 12 . Occupancy of LH receptors ranged between 3 and $13 \%$, and increased significantly between day 4 and day 12 in Groups 3 and 4. However, there was no significant difference in $\mathrm{LH}$ receptor affinity between ewes with adequate or inadequate groups $\mathrm{CL}$ on day 12 (Group 3, $K_{\mathrm{a}}=0.48 \pm 0.12 \quad(n=7) ; \quad$ Group $4, \quad K_{\mathrm{a}}=0.38 \pm 0.1$ $(n=5)$; Groups 1, 2 and 5 combined, $K_{\mathrm{a}}=0.4 \pm 0.12$ $(n=12)$; all $K_{\mathrm{a}}$ data are $\times 10^{10} \mathrm{M}^{-1}$; data not shown).

\section{Morphological studies}

There were no significant differences between the different morphological characteristics of $\mathrm{CL}$ from treatment Groups 1, 2 and 5 in terms of luteal weight, hCG receptors, progesterone content, basal or maximal progesterone secretion in vitro, or luteal sensitivity $\left(\mathrm{EC}_{50}\right)$ to hCG (see below). Therefore data from $\mathrm{CL}$ from Groups 1,2 and 5 were combined for comparison of their morphology with groups with adequate CL (Group 3 and 4).

In all treatment groups there was a significant increase in the total number of cells in $\mathrm{CL}$ recovered on day 12 compared with day 4 (Table 3). Moreover, total cell number per $\mathrm{CL}$ was significantly greater in $\mathrm{CL}$ of the breeding season than either adequate (Group 4) or inadequate (Groups 1, 2 and 5) $\mathrm{GnRH}$-induced CL. In contrast, the number of large luteal cells (diameter $>15 \mu \mathrm{m}$ ) was similar at both stages of the luteal phase, and between treatment groups (Table 3). However, luteal cell volume was significantly greater in breeding season $\mathrm{CL}$ (day 12 vs day 4; $P<0.01$ ), and in Group 3 ewes versus inadequate groups $(P<0.05)$ on day 12 . Luteal vascular surface area was significantly greater on day 12 than on day 4 in all groups, and in breeding season CL compared with adequate (Group 4) or inadequate (Groups 1, 2 and 5) $\mathrm{GnRH}$ induced $\mathrm{CL}(P<0.05$; Table 3$)$. 

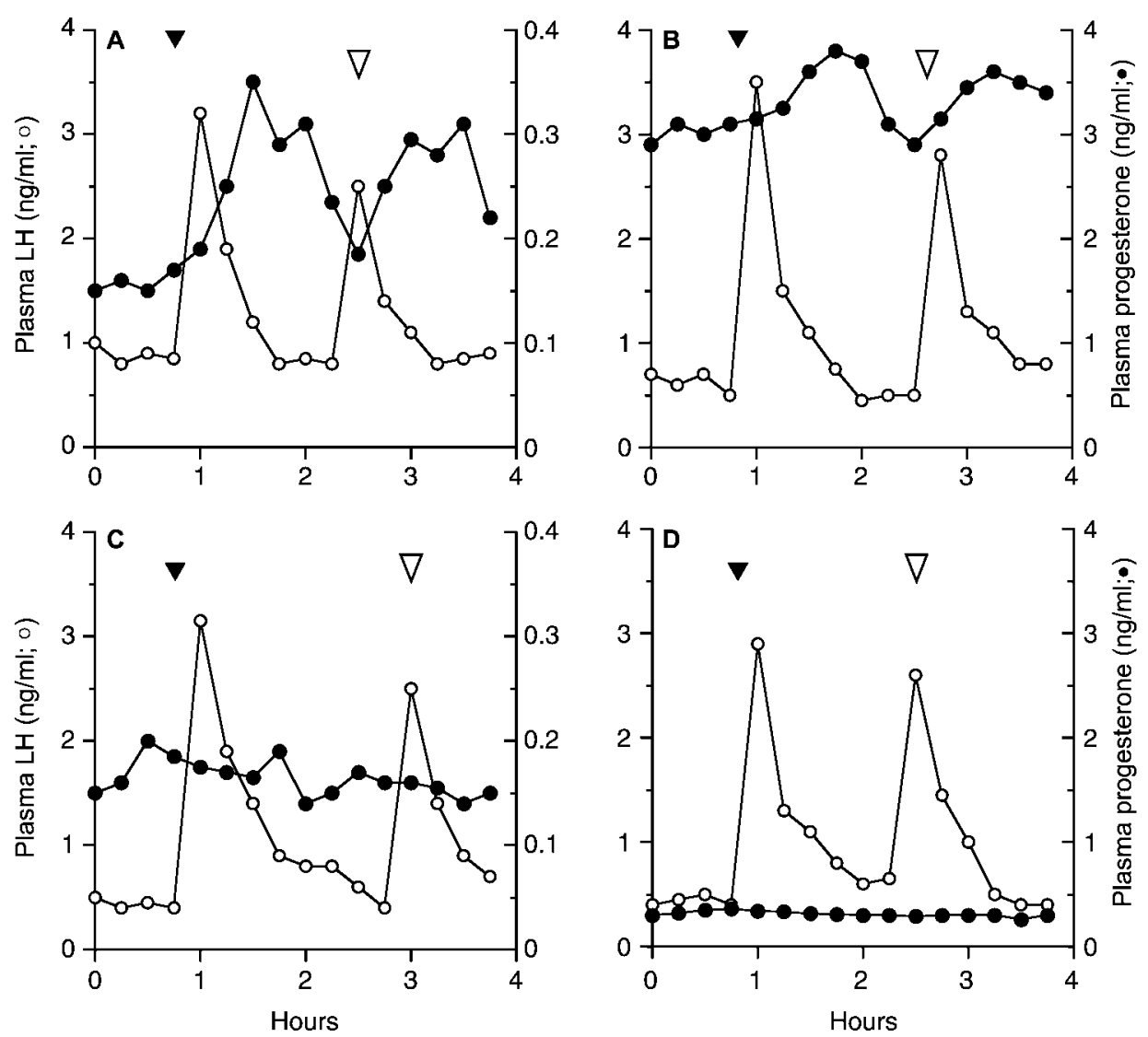

Figure 4 Plasma progesterone concentrations in response to exogenous and endogenous oLH pulses in vivo. Anoestrous ewes were treated as described in the Materials and Methods section and injected with $10 \mu \mathrm{g}$ oLH (solid arrowheads) on either day 3 (A, B) or day 11 (C, D) of the luteal phase. Blood samples were collected every 15 mins for $4 \mathrm{~h}$, and plasma levels of oLH (०) and progesterone ( $\bullet$ ) were measured by immunoassay. (A) Day 3 (adequate CL; Group 3); (B) day 11 (adequate CL; Group 4); (C) day 3 (inadequate CL; Group 5); (D) day 11 (inadequate CL; Group 5). Points are means of triplicate assays for a single representative animal from each group. Solid arrowheads indicate point of exogenous oLH injection; open arrowheads indicate an endogenous LH pulse.

\section{In vitro studies of progesterone secretion}

Pilot experiments showed that progesterone secretion with $0,0.1$ or $10 \mathrm{IU} \mathrm{hCG} / \mathrm{ml}$ increased linearly for up to $3 \mathrm{~h}$ (Fig. 5A). Dose-response curves for hCG became progressively flatter with increasing duration of incubation due to rising basal secretion, although $\mathrm{EC}_{50}$ for hCG did not change (Fig. 5B). A standard incubation time of $2 \mathrm{~h}$ was therefore used for dose-response studies of hCG stimulation of progesterone secretion by luteal tissue minces from experimental groups. Basal progesterone

Table 2 Characteristics of $\mathrm{CL}$ induced by $\mathrm{GnRH}$ during anoestrus and $\mathrm{CL}$ formed during the breeding season. All luteal structures were included in the analysis, irrespective of premature falls in plasma progesterone levels. Data are means \pm S.E.M.

\begin{tabular}{|c|c|c|c|c|c|c|}
\hline \multirow[b]{2}{*}{ Group } & \multirow[b]{2}{*}{ Day } & \multirow[b]{2}{*}{ CL number } & \multirow[b]{2}{*}{ Luteal weight (mg) } & \multirow[b]{2}{*}{ Progesterone content (pg/mg protein) } & \multicolumn{2}{|c|}{ 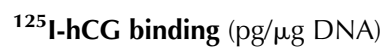 } \\
\hline & & & & & Unoccupied & Occupied \\
\hline 1 & 4 & 2 & $110 \pm 63$ & $14.2 \pm 2.1$ & $3.8 \pm 1.9$ & n.d. \\
\hline 2 & 4 & 4 & $118 \pm 35$ & $15.8 \pm 3.7$ & $3.5 \pm 2.1$ & n.d. \\
\hline 3 & 4 & 6 & $203 \pm 29^{a}$ & $85.3 \pm 3.6^{\mathrm{a}}$ & $5.7 \pm 1.2$ & $0.34 \pm 0.04$ \\
\hline 4 & 4 & 5 & $113 \pm 18$ & $45.9 \pm 2.8^{\mathrm{a}}$ & $4.7 \pm 1.0$ & $0.28 \pm 0.03$ \\
\hline 5 & 4 & 4 & $127 \pm 12$ & $13.8 \pm 1.7$ & $2.1 \pm 0.7$ & $0.27 \pm 0.05$ \\
\hline 1 & 12 & 3 & $340 \pm 30^{b}$ & $19.7 \pm 2.3$ & $8.7 \pm 2.9^{b}$ & n.d. \\
\hline 2 & 12 & 5 & $399 \pm 10^{b}$ & $16.2 \pm 4.1$ & $9.2 \pm 2.3^{b}$ & n.d. \\
\hline 3 & 12 & 7 & $569 \pm 50^{a, b}$ & $47.5 \pm 5.2^{\mathrm{a}, \mathrm{b}}$ & $19.5 \pm 4.3^{a, b}$ & $0.65 \pm 0.08^{b}$ \\
\hline 4 & 12 & 5 & $397 \pm 34^{\mathrm{b}}$ & $28.7 \pm 3.5^{\mathrm{a}, \mathrm{b}}$ & $14.8 \pm 2.1^{\mathrm{a}, \mathrm{b}}$ & $0.58 \pm 0.07^{b}$ \\
\hline 5 & 12 & 5 & $338 \pm 91^{\mathrm{b}}$ & $15.6 \pm 2.8$ & $7.9 \pm 3.2^{\mathrm{b}}$ & $0.31 \pm 0.04$ \\
\hline
\end{tabular}

n.d., not determined.

${ }^{\text {a }}$ Significantly different from inadequate groups $(P<0.05)$.

${ }^{\mathrm{b}}$ Significantly different from same group on day $4(P<0.05)$. 
Table 3 Morphological characteristics of breeding-season and GnRH-induced CL. All luteal structures were included in the analysis, irrespective of premature falls in plasma progesterone levels. Data are means \pm S.E.M.

\begin{tabular}{lccccccc}
\hline Group & Day & CL number & $\begin{array}{c}\text { Total cell number } \\
\text { (millions) }\end{array}$ & $\begin{array}{c}\text { Luteal cell number } \\
(\text { millions })\end{array}$ & $\begin{array}{c}\text { Luteal cell volume } \\
\left(\mu \mathrm{m}^{3} \times 10^{-3}\right)\end{array}$ & $\begin{array}{c}\text { DNA content } \\
(\mathrm{mg} / \mathrm{CL})\end{array}$ & $\begin{array}{c}\text { Vascular surface area } \\
(\mathrm{cm})\end{array}$ \\
\hline 3 & 4 & 6 & $87 \pm 13$ & $51 \pm 10$ & $5.9 \pm 1.8$ & $0.71 \pm 0.11$ & $61 \pm 8$ \\
4 & 4 & 5 & $63 \pm 10$ & $45 \pm 8$ & $5.4 \pm 1.3$ & $0.52 \pm 0.08$ & $54 \pm 9$ \\
$1,2,5$ & 4 & 10 & $56 \pm 11$ & $48 \pm 6$ & $4.9 \pm 1.4$ & $0.46 \pm 0.09$ & $48 \pm 7$ \\
3 & 12 & 7 & $274 \pm 2 *^{\mathrm{a}}$ & $76 \pm 9$ & $16.9 \pm 2.4 *^{\mathrm{a}}$ & $2.23 \pm 0.1 *^{\mathrm{a}}$ & $239 \pm 15 *^{\mathrm{a}}$ \\
4 & 12 & 5 & $194 \pm 13 *^{\mathrm{a}, \mathrm{b}}$ & $53 \pm 8$ & $10.3 \pm 2.1$ & $1.58 \pm 0.11 *^{\mathrm{a}, \mathrm{b}}$ & $172 \pm 12 *^{\mathrm{a}, \mathrm{b}}$ \\
$1,2,5$ & 12 & 13 & $135 \pm 1 *^{\mathrm{a}, \mathrm{c}}$ & $49 \pm 8$ & $9.3 \pm 1.9^{\mathrm{b}}$ & $1.10 \pm 0.1 *^{\mathrm{a}, \mathrm{c}}$ & $112 \pm 11 *^{\mathrm{a}, \mathrm{c}}$ \\
\hline
\end{tabular}

Values within columns with different superscript letters are significantly different $(P<0.05)$.

* Significantly different from day $4(P<0.01)$.

secretion by luteal tissue from day 4 of the luteal phase was significantly higher $(P<0.05)$ than on day 12 of the luteal phase for all groups (cf Fig. 6A and B). However, maximal responses to hCG or dbcAMP were similar on day 4 and day 12 for all treatment groups (Fig. 6). Dose-response curves for luteal tissue from inadequate CL (Groups 1, 2 and 5) on both day 4 (Fig. 7A) and day 12 (Fig. 7B) of the luteal phase were not significantly different $\left(\mathrm{EC}_{50}\right.$, $1.0 \mathrm{IU}$ hCG/ml; Table 4). In contrast, $\mathrm{EC}_{50}$ concentrations for adequate CL (Groups 3 and 4) were 10-fold lower on both days 4 and $12\left(E_{50}, 0.1 \mathrm{IU} h \mathrm{hCG} / \mathrm{ml}\right.$; Table 4; $P<0.05)$.

\section{Discussion}

\section{Ovulatory response to GnRH and luteal lifespan}

Our data have confirmed and extended a number of earlier studies showing that bolus injections of $\mathrm{GnRH}$ (Crighton et al. 1973, 1975, McNeilly et al. 1981) or multiple frequent injections of low doses of GnRH (Crighton et al. 1975, McLeod et al. 1982a, 1982b) induced ovulation in a proportion of ewes during seasonal anoestrus, but that the resulting CL were smaller, and produced less progesterone than those of the normal luteal phase of the cycle (McNeilly et al. 1981, O'Shea et al. 1984). All four GnRH-treatment regimens used induced ovulation during anoestrus, although the proportion of ewes ovulating in response to the different treatments did not differ significantly between groups (Table 1). Only ewes in Group 3 (breeding season) and Group 4 (anoestrous animals pretreated with progestagen and given an increasing frequency of GnRH injections) had profiles of progesterone secretion consistent with adequate luteal function (Fig. 2A).

Interestingly, progestagen pretreatment prior to an ovulatory stimulus did not result in the formation of adequate $\mathrm{CL}$ in anoestrous Welsh Mountain ewes (Group 2 vs Group 1; Table 1). This contrasts with many other studies in a number of different sheep breeds, using a range of ovulatory stimuli (e.g. GnRH, pregnant mares' serum gonadotrophin, ram effect during anoestrus). The reasons for the failure of progesterone to promote the formation of adequate $\mathrm{CL}$ are unclear. Basal LH levels, LH pulse frequency and $\mathrm{LH}$ pulse amplitude were similar in the two groups prior to $\mathrm{GnRH}$ treatment, as were the magnitude
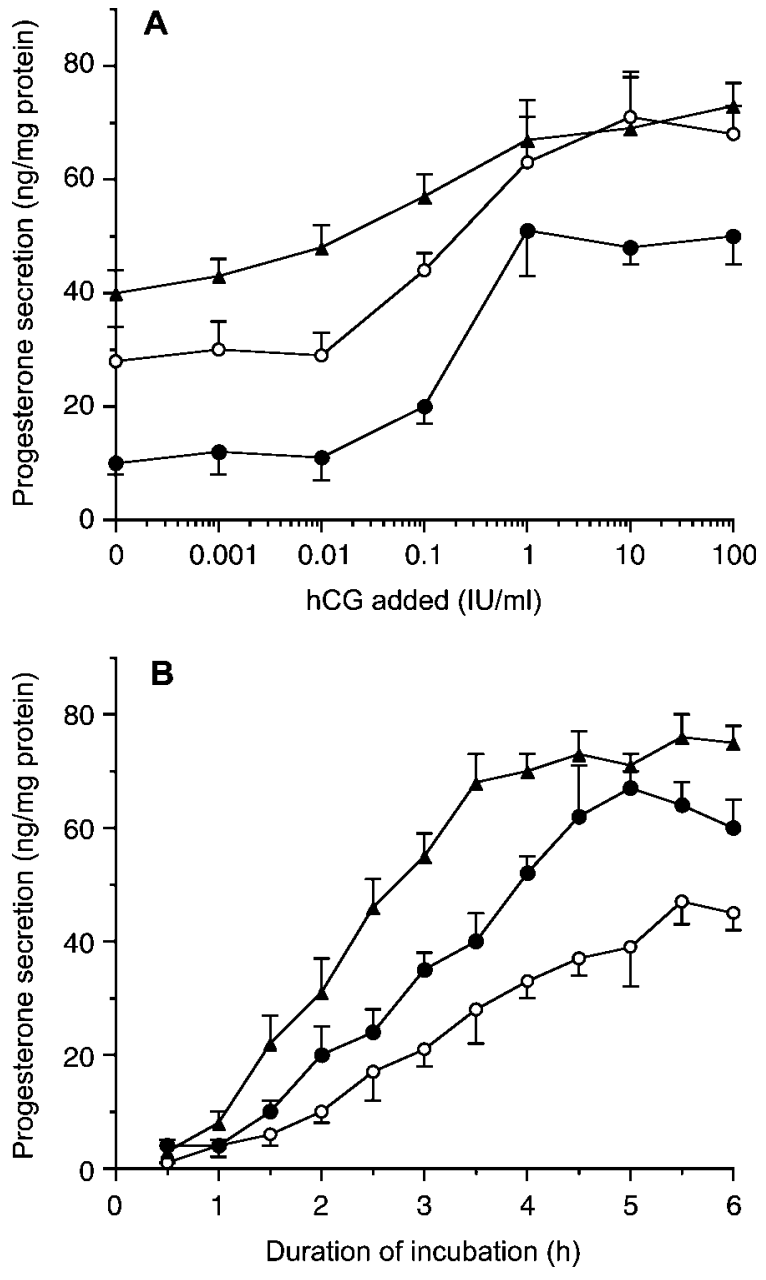

Figure 5 Progesterone secretion in response to hCG by ovine luteal tissue in vitro. (A) Mid-luteal-phase CL were obtained from a local abattoir and transported to the laboratory within $1 \mathrm{~h}$. Triplicate aliquots of minced mid-luteal tissue were incubated in $\mathrm{M} 199$ at $37^{\circ} \mathrm{C}$ in the presence of increasing concentrations of hCG $(0.1 \mathrm{mlU} / \mathrm{ml}-$ $100 \mathrm{IU} / \mathrm{ml}$ ) and incubated for $2 \mathrm{~h}(\bullet), 4 \mathrm{~h} \mathrm{( \circ )}$ or $6 \mathrm{~h} \mathrm{( \Delta ).} \mathrm{Points} \mathrm{are}$ means \pm range from two experiments in triplicate. (B) Triplicate aliquots of minced luteal tissue were incubated with shaking in M199

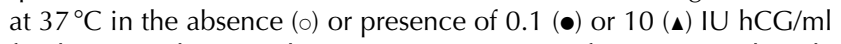
for the times shown. Tubes were spun at $5000 \mathrm{~g}$ for $10 \mathrm{~min}$ and medium decanted and assayed for progesterone. Points are means \pm range from two experiments in triplicate. 

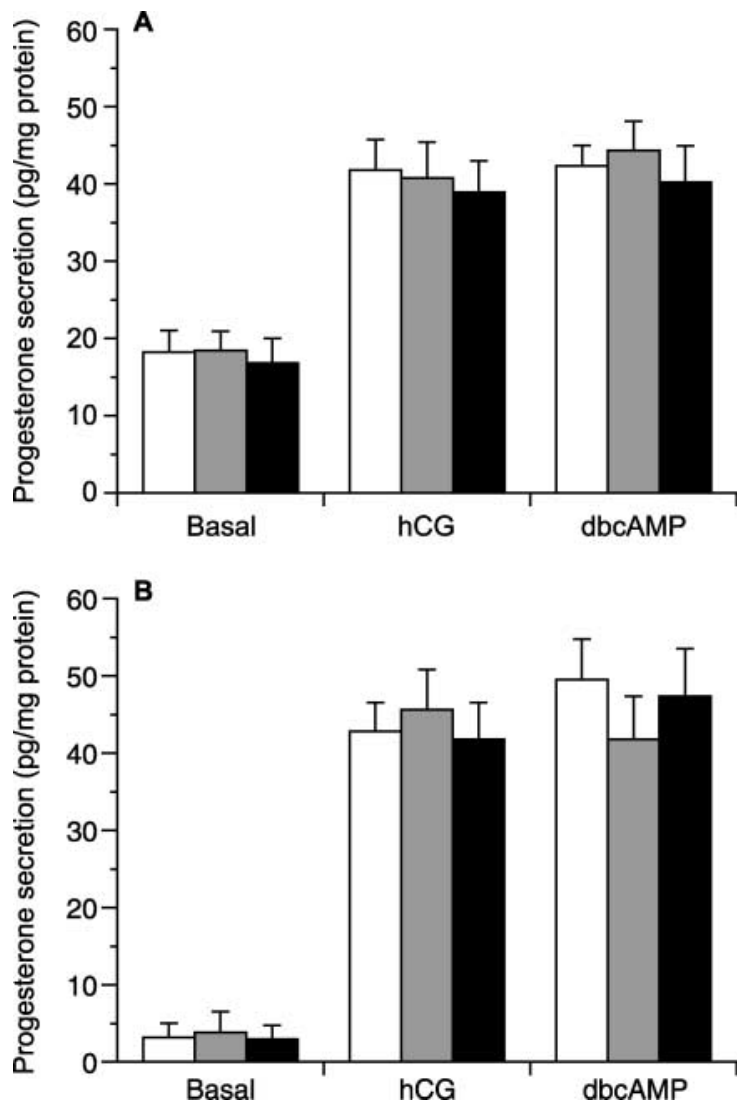

Figure 6 Progesterone secretion by luteal tissue from the different experimental groups on day 4 (A) or day 12 (B) of the luteal phase, incubated with or without $10 \mathrm{IU} / \mathrm{ml} \mathrm{hCG}$ or $0.5 \mathrm{mM}$ dbcAMP in vitro. Luteal tissue was recovered from the different treatment groups on either day 4 (A) or day 12 (B). Tissue was minced finely and triplicate aliquots were incubated for $2 \mathrm{~h}$ in $\mathrm{M} 199$ at $37^{\circ} \mathrm{C}$ in the presence of $100 \mathrm{IU} / \mathrm{ml}$ hCG or $0.5 \mathrm{mM}$ dbc AMP. Open columns, inadequate induced luteal tissue (Groups 1, 2 and 5); hatched columns, adequate induced luteal tissue (Group 4); solid columns, breeding-season luteal tissue (Group 3). Column heights represent means and vertical bars are S.E.M. for $n$ animals/group, as shown in the legend to Figure 2.

and duration of the LH surge induced (Table 1), ruling out an effect of progesterone on the pituitary gland. It will be of interest to test whether this refractoriness is a consequence of the deep anoestrus experienced by this breed of sheep at higher latitudes, requiring longer duration of exposure to (and/or higher/lower concentrations of) progestagen to prime the ovary to respond.

Luteal function was defined as 'inadequate' when plasma progesterone levels did not exceed $1.5 \mathrm{ng} / \mathrm{ml}$ for at least 2 consecutive days. This broad definition includes both short luteal phases and extended luteal phases with reduced progesterone (Xiao et al. 2002). Both types of inadequate luteal phase were present in Groups 1,2 and 5: (a) 'short' luteal phases, characterized by a decline in progesterone to baseline levels within 8 days and (b) extended luteal phases that were maintained until day 12 , but with reduced progesterone secretion (see Fig. 2B). Extended luteal phases were associated with higher
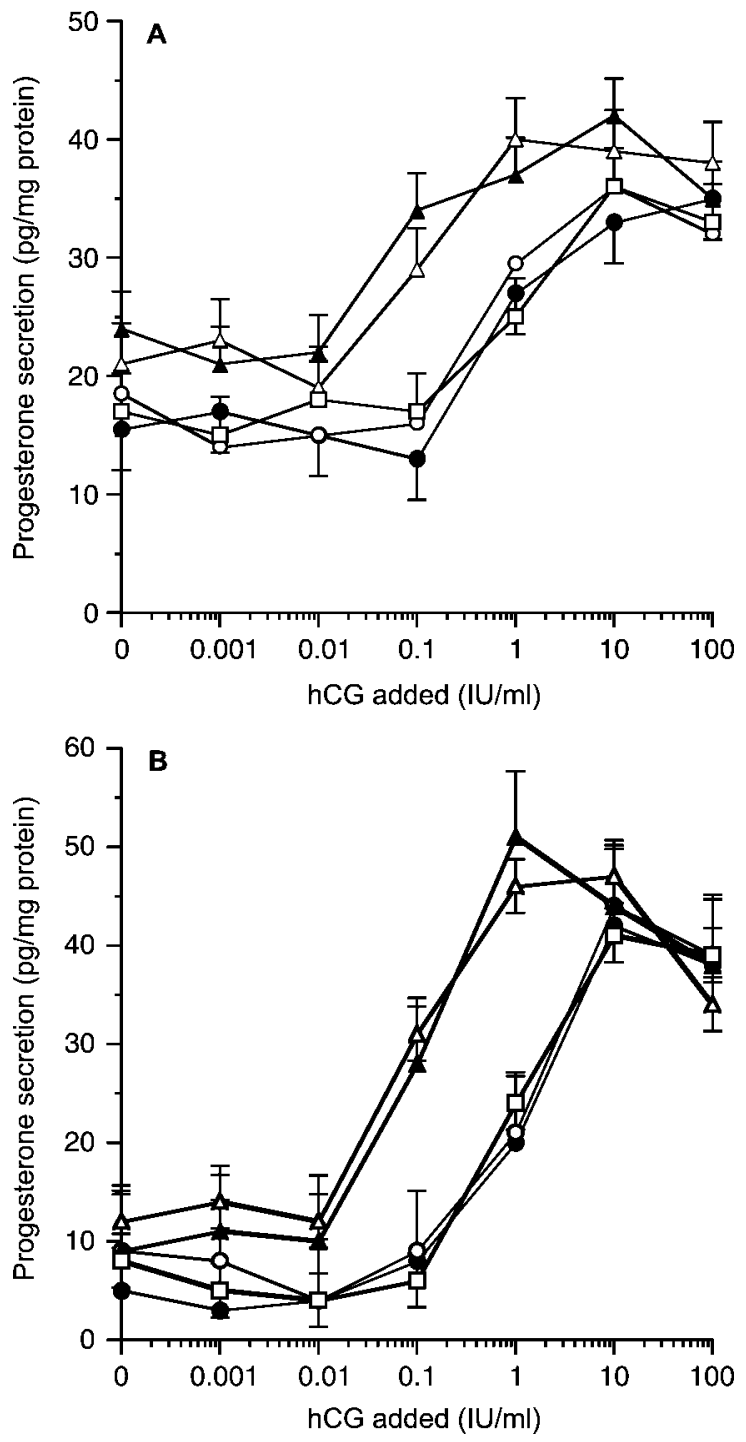

Figure 7 Progesterone secretion by luteal tissue minces from the different treatment groups in response to increasing doses of hCG in vitro. Luteal tissue recovered from the different treatment groups on either day 4 (A) or day 12 (B) was minced and triplicate aliquots were incubated for $2 \mathrm{~h}$ in $\mathrm{M} 199$ at $37^{\circ} \mathrm{C}$ in the presence of increasing doses $(0.1 \mathrm{mlU}-100 \mathrm{IU} / \mathrm{ml})$ of hCG. Tubes were spun at $5000 \mathrm{~g}$ for $10 \mathrm{~min}$ and medium decanted and assayed for progesterone. Values were adjusted for DNA content of cell pellets. Group $1(\bullet)$;

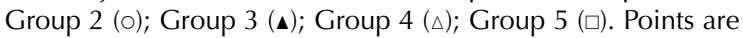
means \pm S.E.M. for $n$ animals in each group, as shown in the legend to Figure 2.

plasma prolactin levels, suggesting that prolactin may affect luteal phase length. However, short-term pharmacological suppression of prolactin failed to alter luteal lifespan in anoestrous GnRH-treated (Group 5) ewes (McNeilly \& Land 1979) or pituitary stalk-disconnected ewes (Niswender et al. 1986), and pharmacological elevation of prolactin failed to prevent luteolysis induced by prostaglandin $F_{2 \alpha}$ (Sasser et al. 1977). Due to small numbers of $\mathrm{CL}$, a direct comparison of the characteristics of 'short' and 'peristent' inadequate luteal phases in the 
Table 4 Dose of hCG required to give half-maximal stimulation $\left(\mathrm{EC}_{50}\right)$ of progesterone secretion in vitro by luteal tissue from each group. Data are means \pm S.E.M.

\begin{tabular}{lccc}
\hline Group & Day & CL number & EC $_{\mathbf{5 0}}$ concentration $(\mathrm{IU} \mathrm{hCG} / \mathrm{ml})$ \\
\hline 1 & 4 & 2 & $0.91 \pm 0.05$ \\
2 & 4 & 4 & $0.97 \pm 0.09$ \\
3 & 4 & 6 & $0.11 \pm 0.01^{*}$ \\
4 & 4 & 5 & $0.09 \pm 0.02^{*}$ \\
5 & 4 & 4 & $0.95 \pm 0.06$ \\
1 & 12 & 3 & $1.06 \pm 0.12$ \\
2 & 12 & 5 & $0.99 \pm 0.11$ \\
3 & 12 & 7 & $0.10 \pm 0.02^{*}$ \\
4 & 12 & 5 & $0.09 \pm 0.03^{*}$ \\
5 & 12 & 5 & $1.11 \pm 0.13$ \\
\hline
\end{tabular}

* Significantly different from Groups 1,2 and $5(P<0.05)$.

same treatment groups was not possible. However, it would be interesting to study whether persistent 'low-progesterone' CL were nevertheless capable of supporting a pregnancy, and whether luteal lifespan was affected by the presence of developing large ovarian follicle(s) in the same ovary.

\section{Morphology of the $C L$}

Morphologically, the total number of cells per CL increased between day 4 and day 12 for all groups (Table 4). Our data for total cell numbers per CL were similar to those reported by O'Shea et al. (1984) and Braden et al. (1989), but lower than those reported by Farin et al. (1990) in superovulated ewes. Total cell number was highest in day $12 \mathrm{CL}$ from ewes during the breeding season, and was significantly greater in ewes with adequate CL (Group 4) than inadequate CL (Groups 1, 2 and 5). Luteal DNA content (an indirect measure of the number of cell nuclei) correlated well with total cell number per CL (Table 4).

The number of large luteal cells $(>15 \mu \mathrm{m}$ diameter) was similar in all groups on both days (Table 3), in agreement with Braden et al. (1989), but in contrast to the data of O'Shea et al. (1984). However, mean luteal cell volume increased significantly from day 4 to day 12 (Group 3), and was significantly greater for CL formed in the breeding season compared with groups with inadequate CL (Table 4), in contrast to the study by O'Shea et al. (1984). Mean vascular area was similar for all CL on day 4 (Table 4 ), but increased 3-4-fold by day 12 in all groups, and was maximal in breeding season CL compared with either adequate (Group 4) or inadequate (Groups 1, 2 and 5) CL (Table 4), emphasizing the importance of the development of the luteal vascular system for adequate CL function (Schams \& Berisha 2004, Tamanini \& De Ambrogi 2004).

The morphometric methods used in this study were subject to a number of caveats. First, the distribution of cellular components within different regions of the ovine $\mathrm{CL}$ is not uniform (Gilbert et al. 1990). We attempted to overcome this by processing segments of luteal tissue from different regions (cortex and medulla) of the CL. Each segment was then chopped finely into $1 \mathrm{~mm}^{3}$ pieces that were individually immersion-fixed and processed, and then 510 of these were selected at random for embedding and processing. Moreover, preliminary experiments comparing the effects of counting different numbers of grid squares per field of view on luteal tissue demonstrated that counting four grids gave similar estimates of mean cell counts and variance to counts of ten or more grids (D. Stirling, unpublished observations), assuring us that our methods were statistically reliable. Indeed, a consistent change in a measured parameter in $n>4$ animals is reported to have a probability of $P<0.05$ (Cruz-Orive \& Weibel 1990).

Secondly, the effects of fixation cause significant cell shrinkage and affect measurement of vascular space (Dharmarajan et al. 1983, 1985). Since luteal weights and the consistency of luteal tissue varied with both treatment group and stage of luteal phase, fixation effects may vary between treatment groups and luteal stage. Perfusion fixation of $\mathrm{CL}$ was not possible in this study. Furthermore, because the experiments were performed at different times of the year, morphological comparisons could not be made between $C L$ processed for histology at the same time, under identical conditions.

Thirdly, assumptions of a spherical shape for luteal cells in situ may not be valid (T.A. Bramley, unpublished observations).

For these reasons, the morphological data obtained must be treated with some caution. Having said this, many of the changes we observed were generally consistent with previous histological findings $\left(\mathrm{O}^{\prime}\right.$ Shea et al. 1984, Rodgers et al. 1984, Braden et al. 1989, Farin et al. 1990). Furthermore, there was also some measure of internal consistency in our data. Taking the average DNA content of a cell as $6 \mathrm{pg}$, measurements of total cell number appeared to be underestimated by approximately $25-30 \%$. Rodgers et al. (1984) found a ratio of cell counts/DNA content of $97 \%$. In our study, this ratio, though lower, was consistent between the different treatment groups. Interestingly, some of the morphological characteristics of $\mathrm{GnRH}$-induced inadequate $\mathrm{CL}$ (fewer $\mathrm{LH}$ receptors, lower luteal progesterone content, fewer total cells per $\mathrm{CL}$ and reduced luteal cell volume) resemble those seen in $\mathrm{CL}$ induced in hypophysectomized ewes (Farin et al. 1990). Moreover, Fitz et al. (1982) demonstrated that injection of hCG during the luteal phase caused a shift in the size distribution of luteal cells, increasing the proportion of larger cell types. Thus, some of the morphological changes observed in the present study are also suggestive of an inability of GnRH-induced $\mathrm{CL}$ to respond to the luteotrophic effects of $\mathrm{LH}$ in vivo.

\section{Luteal $L H$ responsiveness in vivo}

Ewes injected with a bolus of exogenous oLH on day 3 or day 11 of the luteal phase during the breeding season demonstrated a rapid and significant increase in plasma progesterone levels (Fig. 3A and D; note the 10-fold difference in progesterone levels between days 3 and 11). 
A similar progesterone response was observed for ewes in Group 4 (adequate $\mathrm{CL}$ ) on both days (Fig. 3B and E). In contrast, oLH injection of ewes in Groups 1, 2 and 5 (inadequate $\mathrm{CL}$ ) failed to elicit a significant progesterone response, despite generating an LH pulse of similar magnitude (Fig. 3C and F). This observation was confirmed serendipitously in ewes that had a spontaneous peak of endogenous $\mathrm{LH}$ during the $4 \mathrm{~h}$ blood-sampling window (Fig. 4). Endogenous LH peaks were similar in magnitude and duration to oLH peaks generated by injection of exogenous $\mathrm{LH}$ in groups of ewes with adequate or inadequate CL. However, whereas a rise in plasma progesterone occurred of similar magnitude to that produced in response to exogenous $\mathrm{LH}$ injection following an endogenous $\mathrm{LH}$ pulse in ewes with an adequate $\mathrm{CL}$ (Groups 3 and 4), no significant response was observed to either exogenous or endogenous LH peaks in ewes with an inadequate $\mathrm{CL}$ (Groups 1, 2 and 5). Furthermore, the inability to respond to an $\mathrm{LH}$ pulse in vivo was apparent on day 3 in ewes that were destined to form an inadequate $\mathrm{CL}$ (Figs 3B, 3E, 4A and 4B), despite the fact that progesterone secretion in vivo was not distinguishable from that of adequate $\mathrm{CL}$ at this stage (Fig. 2). This suggests that the steroidogenic potential of these $\mathrm{CL}$ was already compromised by day 3. Similar findings have been reported in Romney Marsh ewes (on days 4-6 after ovulation; Hunter et al. 1988, Southee et al. 1988a), in Corriedale ewes (on days 8, 9 and 10; O'Shea et al. 1984, Rodgers et al. 1984) and in Scottish Blackface ewes (on day 5; McNeilly et al. 1981). We also found that luteal progesterone content was significantly reduced in the three groups of ewes with inadequate CL compared with those with adequate CL (Table 2). However, in contrast to the data of McNeilly et al. (1981) and Hunter et al. (1988), luteal progesterone content was higher in both groups with adequate CL on day 4 than later in the luteal phase (Table 2 ). This may reflect upregulation of steroidogenic enzymes (with a consequent increase in steroid synthesis) prior to the establishment of an adequate luteal vascular system to remove synthesized steroids into the general circulation.

\section{Luteal $L H$ responsiveness in vitro}

Previous studies of progesterone secretion by ovine luteal tissue in vitro have used quite different tissue preparations and/or incubation conditions. Thus, Braden et al. (1989) and Chemineau et al. (1993) studied progesterone secretion by enzymically dispersed luteal cells, whereas Hunter et al. (1988) used luteal slices and McNeilly et al. (1981) studied luteal minces. Moreover, the incubation media used, the amount of tissue or number of cells per incubation, and the duration of incubation used (from 3 to $12 \mathrm{~h}$ ) varied markedly between studies. The present results differ from those of previous studies in a number of important respects. First, we used hCG in preference to oLH, as Hunter et al. $(1986,1988)$ have shown that ovine luteal tissue binds hCG with an affinity 3-30-fold higher than that of oLH. Secondly, we used luteal minces, as the conditions used to disperse luteal tissue (1) significantly reduced luteal LH receptor levels, possibly compromising steroidogenic response in vitro (T.A. Bramley and G.S. Menzies, unpublished observations), and (2) disrupted cell-cell communication, which may be important for normal progesterone secretion (Harrison et al. 1987, Del Vecchio et al. 1994, Grazul-Bilska et al. 2001). Under our incubation conditions, progesterone secretion increased linearly with duration of incubation (both in the absence and presence of hCG) for up to $3 \mathrm{~h}$ (Fig. 5A). However, basal progesterone secretion increased progressively with increasing duration of incubation, leading to an apparent flattening of the dose-response curve (Fig. $5 B$ ). These factors make direct comparison of our data on steroid secretion and hormonal responsiveness with data obtained by other groups difficult, but may account for the failure of some studies (Braden et al. 1989, Chemineau et al. 1993) to demonstrate a significant progesterone response to $\mathrm{LH}$ in vitro.

Studies of in vitro progesterone secretion by $\mathrm{CL}$ minces from tissue recovered following the different treatments on days 4 or 12 revealed some interesting points. First, basal progesterone secretion by $\mathrm{CL}$ of all groups was significantly higher on day 4 than on day 12 (Fig. 6), in line with luteal progesterone content (Table 2). In contrast, maximal response to hCG or to dbcAMP was not significantly different at either stage or between different treatment groups (Fig. 6). However, although maximal response to hCG was similar for the groups with adequate and inadequate $\mathrm{CL}$, we observed a dramatic right-shift in the dose-response curves for hCG in inadequate $\mathrm{CL}$ (Groups 1, 2 and 5; Fig. 7) compared with breeding season CL (Group 3) and adequate induced CL (Group 4), resulting in a significant 10 -fold difference in $\mathrm{EC}_{50}$ for hCG for adequate and inadequate luteal tissue that was apparent in both day 4 and day 12 (Fig. 7, Table 4). This is in line with our in vivo data that showed that $\mathrm{CL}$ that are inadequate, or are destined to become inadequate, failed to respond to a pulse of $\mathrm{LH}$ with increased progesterone secretion (Figs 3 and 4). Although LH receptor numbers were reduced in inadequate $\mathrm{GnRH}$-induced $\mathrm{CL}$ relative to adequate $\mathrm{CL}$ groups (Table 2; see also McNeilly et al. 1981 and Hunter et al. 1988), inadequate luteal tissue still responded maximally to both dbcAMP and high doses of hCG (Figs 6 and 7). The change in $\mathrm{EC}_{50}$ suggested a change in LH-/hCG-binding affinity; however, there were no significant differences in $K_{\mathrm{a}}$ for ${ }^{125} \mathrm{I}$-hCG binding to luteal homogenates from the different treatment groups on days 4 or 12 (see above). Finally, differing luteal sensitivity could not be accounted for by differing $\mathrm{LH}$ receptor occupancy (Table 2).

In conclusion, we have shown that Welsh Mountain ewes can be induced to ovulate during anoestrus using different GnRH-injection protocols. However, the $\mathrm{CL}$ so formed (1) are abnormal morphologically and biochemically, and show characteristics suggestive of inadequate 
luteinization and/or LH stimulation, (2) exhibit a markedly diminished progesterone response to oLH injection in vivo and (3) demonstrate a markedly reduced sensitivity of progesterone secretion in vitro to hCG (an order of magnitude), but show no change in maximal response to either dbcAMP and hCG, suggestive of a profound but subtle defect in the efficacy of LH receptor-second messenger coupling.

Thus, in addition to their well-established premature sensitivity to uterine prostaglandin $F_{2 \alpha}$, we have shown that ovulation induced by GnRH injection during anoestrus results in the formation of $\mathrm{CL}$ that show defective coupling of $\mathrm{LH}$ receptors to downstream intracellular signal transduction pathways. It will be of interest to examine the effects of luteotrophic and luteolytic agents that are known to activate different luteal cell signalling pathways (Niswender 2002, Davis and Rueda 2002) on the responsiveness of these induced $\mathrm{CL}$, in vivo and in vitro, and thereby elucidate the cause of their reduced LH sensitivity.

\section{Acknowledgements}

We wish to thank the staff of the Large Animal Unit of the Roslin Institute for their assistance with animal handling and blood sampling, Professor Alan McNeilly for provision of antisera for RIAs, and the staff of the Department of Pathology, Edinburgh University, for their assistance with luteal cell morphometry. This work was supported in part by grants (D S, T A B and D T B) from the Medical Research Council, UK.

\section{References}

Atkinson S 1988 Inadequate function of corpora lutea following the induction of ovulation with monensin and FSH in seasonally anoestrous ewes. Journal of Endocrinology 117 167-172.

Backstrom T, Carlstrom K, von Schoultz B \& Toivonen J 1982 Effect of progesterone, administered via intravaginal rings, on serum concentrations of oestradiol, FSH, $\mathrm{LH}$ and prolactin in women. Journal of Reproduction and Fertility 64 53-58.

Bartlewski PM, Beard AP, Chapman CL, Nelson ML, Palmer B, Aravindakshan J, Cook SJ \& Rawlings NC 2001 Ovarian responses in gonadotrophin-releasing hormone-treated anoestrous ewes: follicular and endocrine correlates with luteal outcome. Reproduction Fertility and Development 13 133-142.

Bartlewski PM, Aravinakshan J, Beard AP, Nelson ML, Batista-Arteaga M, Cook SJ \& Rawlings NC 2004 Effects of medroxyprogesterone acetate (MAP) on ovarian antral follicle development, gonadotrophin secretion and response to ovulation induction with gonadotrophin-releasing hormone $(\mathrm{GnRH})$ in seasonally anoestrous ewes. Animal Reproduction Science 81 63-75.

Beard AP \& Hunter MG 1996 Effects of exogenous oxytocin and progesterone on $\mathrm{GnRH}$-induced short luteal phases in anoestrous ewes. Journal of Reproduction and Fertility 106 55-61.

Braden TD, Sawyer HR \& Niswender GD 1989 Functional and morphological characteristics of the first corpus luteum formed after parturition in ewes. Journal of Reproduction and Fertility $\mathbf{8 6}$ 525-533.

Bramley TA, Stirling D, Swanston IA, Menzies GS, McNeilly AS \& Baird DT 1987 Specific binding sites for gonadotrophin-releasing hormone, LH/chorionic gonadotrophin, low density lipoprotein, prolactin and $\mathrm{FSH}$ in homogenates of human corpus luteum: II Concentrations throughout the luteal phase of the menstrual cycle and early pregnancy. Journal of Endocrinology 13 317-327.
Burton K 1956 A study of the conditions and mechanism of the diphenylamine reaction for the colorimetric estimation of deoxyribonucleic acid. Biochemical Journal 62 315-323.

Chemineau P, Daveau A, Locatelli A \& Maurice F 1993 Ram-induced short luteal phases: effects of hysterectomy and cellular composition of the corpus luteum. Reproduction Nutrition and Development 33 253-261.

Crighton DB, Foster JP, Haresign W, Haynes NB \& Lamming GE 1973 The effects of synthetic preparation of gonadotrophin releasing factor on pituitary and ovarian function in anoestrous ewes. Journal of Physiology (London) 231 98P-99P.

Crighton DB, Foster JP, Haresign W \& Scott SA 1975 Plasma LH and progesterone levels after single or multiple injections of synthetic LH-RH in anoestrous ewes and comparison with levels during the oestrous cycle. Journal of Reproduction and Fertility $\mathbf{4 4}$ $121-124$.

Cruz-Orive LM \& Weibel ER 1990 Recent stereological methods for cell biology: a brief survey. American Journal of Physiology $\mathbf{2 5 8}$ L148-L156.

Davis JS \& Rueda BR 2002 The corpus luteum: an ovarian structure with maternal instincts and suicidal tendencies. Frontiers in Bioscience 7 1949-1978.

Del Vecchio RP, Thibodeaux JK, Randel RD \& Hansel W 1994 Interactions between large and small bovine luteal cells in a sequential perifusion co-culture system. Journal of Animal Science $\mathbf{7 2}$ 963-968.

Dharmarajan AM, Meyer GT \& Bruce NW 1983 Morphometric analysis of the corpus luteum of 16-day pregnant rats: The effect of preparative procedures on volume of luteal cell, interstitial, and vascular components. American Journal of Anatomy 168 51-65.

Dharmarajan AM, Bruce NW \& Meyer GT 1985 Quantitative ultrastructural characteristics relating to transport between luteal cell cytoplasm and blood in the corpus luteum of the pregnant rat. American Journal of Anatomy 172 87-99.

Djahanbakhch O, McNeilly AS, Hobson BM \& Templeton AA 1981 A rapid luteinizing hormone radioimmunoassay for the prediction of ovulation. British Journal of Obstetrics and Gynaecology $\mathbf{8 8}$ 1016-1020.

Farin CE, Nett TM \& Niswender GD 1990 Effects of luteinizing hormone on luteal cell populations in hypophysectomized ewes. Journal of Reproduction and Fertility $\mathbf{8 8} 61-70$.

Fitz TA, Mayan MH, Sawyer HR \& Niswender GD 1982 Characterization of two steroidogenic cell types in the ovine corpus luteum. Biology of Reproduction 27 703-711.

Garverick HA, Zollers WG Jr \& Smith MF 1992 Mechanisms associated with corpus luteum lifespan in animals having normal or subnormal luteal function. Animal Reproduction Science $\mathbf{2 8}$ 111-124.

Gilbert CL, Hunter MG, Southee JA \& Wathes DC 1990 Immunocytochemical localization of oxytocin in corpora lutea and luteinized cysts from anoestrous ewes stimulated with gonadotrophin-releasing hormone. Cell and Tissue Research 262 157-164.

Grazul-Bilska AT, Reynolds LP, Bilski JJ \& Redmer DA 2001 Effects of second messengers on gap junction intercellular communication of ovine luteal cells throughout the estrous cycle. Biology of Reproduction 65 777-783.

Harrison LM, Kenny N \& Niswender GD 1987 Progesterone production, $\mathrm{LH}$ receptors, and oxytocin secretion by ovine luteal cell types on days 6,10 and 15 of the oestrous cycle and day 25 of pregnancy. Journal of Reproduction and Fertility 79 539-548.

Hu Y, Nephew KP, Pope WF \& Day ML 1991 Uterine influences on the formation of subnormal corpora lutea in seasonally anestrous ewes. Journal of Animal Science $692532-2537$.

Hunter MG 1991 Characteristics and causes of the inadequate corpus luteum. Journal of Reproduction and Fertility 43 (suppl) 91-99.

Hunter MG, Southee JA, McLeod BJ \& Haresign W 1986 Progesterone pretreatment has a direct effect on $\mathrm{GnRH}$-induced preovulatory follicles to determine their ability to develop into normal 
corpora lutea in anoestrous ewes. Journal of Reproduction and Fertility 76 349-363.

Hunter MG, Southee JA \& Lamming GE 1988 Function of abnormal corpora lutea in vitro after GnRH-induced ovulation in the anoestrous ewe. Journal of Reproduction and Fertility 84 139-148.

Hunter MG, Ayad VJ, Gilbert CL, Southee JA \& Wathes DC 1989 Role of prostaglandin $\mathrm{F}-2_{\alpha}$ and oxytocin in the regression of $\mathrm{GnRH}$-induced abnormal corpora lutea in anoestrous ewes. Journal of Reproduction and Fertility 85 551-561.

Keisler DH \& Keisler LW 1989 Formation and function of $\mathrm{GnRH}$-induced subnormal corpora lutea in cyclic ewes. Journal of Reproduction and Fertility 87 265-273.

Khalid M, Basiouni GF \& Haresign W 1997 Effect of progesterone pre-treatment on steroid secretion rates and follicular fluid insulinlike growth factor-1 concentrations in seasonally anoestrous ewes treated with gonadotrophin-releasing hormone. Animal Reproduction Science 46 69-78.

Lecocq J 1993 Unbiased 3-D quantification of ultrastructure in cell biology. Trends in Cell Biology 3 354-358.

Legan SJ, I'Anson H, Fitzgerald BP \& Akaydin MS Jr 1985 Importance of short luteal phases in the endocrine mechanism controlling initiation of estrous cycles in anestrous ewes. Endocrinology 117 1530-1536.

Lowry OH, Rosebrough NJ, Farr AL \& Randall RJ 1951 Protein measurement with the Folin phenol reagent. Journal of Biological Chemistry 193 265-275.

Lund SA, Murdoch J, Van Kirk EA \& Murdoch WJ 1999 Mitogenic and antioxidant mechanisms of estradiol action in preovulatory ovine follicles: relevance to luteal function. Biology of Reproduction 61 388-392.

Martin GB, Oldham CM, Cognie Y \& Pearce DT 1986 The physiological responses of anovulatory ewes to the introduction of rams - a review. Livestock Production Science 15 219-247.

McLeod BJ \& Haresign B 1984 Evidence that progesterone may influence subsequent luteal function in the ewe by modulating preovulatory follicle development. Journal of Reproduction and Fertility 71 381-386.

McLeod BJ, Haresign B \& Lamming GE 1982a The induction of ovulation and luteal function in seasonally anoestrous ewes treated with small-dose multiple injections of GnRH. Journal of Reproduction and Fertility 65 215-221.

McLeod BJ, Haresign B \& Lamming GE 1982b Response of seasonally anoestrous ewes to small-dose multiple injections of $\mathrm{GnRH}$ with and without progesterone pretreatment. Journal of Reproduction and Fertility 65 223-230.

McNeilly AS \& Andrews P 1974 Purification and characterization of caprine prolactin. Journal of Endocrinology $60359-367$.

McNeilly AS \& Land RB 1979 Effect of suppression of plasma prolactin on ovulation, plasma gonadotrophins and corpus luteum function in LH-RH treated anoestrous ewes. Journal of Reproduction and Fertility 56 601-609.

McNeilly AS, Hunter M, Land RB \& Fraser HM 1981 Inadequate corpus luteum function after the induction of ovulation in anoestrous ewes by $\mathrm{LH}-\mathrm{RH}$ or $\mathrm{LH}-\mathrm{RH}$ agonist. Journal of Reproduction and Fertility 63 137-144.

McNeilly AS, O'Connell M \& Baird DT 1982 Induction of ovulation and normal luteal function by pulsed injections of luteinizing hormone in anoestrous ewes. Endocrinology $1101292-1299$.

McNeilly AS, Jonassen JA \& Fraser HM 1985 Suppression of follicular development after chronic LHRH immunoneutralization in the ewe. Journal of Reproduction and Fertility 76 481-490.

McNeilly JR, McNeilly AS, Walton JS \& Cunningham FJ 1976 Development and application of a heterologous radioimmunoassay for ovine follicle-stimulating hormone. Journal of Endocrinology 70 69-79.
Niswender GD 2002 Molecular control of luteal secretion of progesterone. Reproduction 123 333-339.

Niswender GD, Farin CE, Gamboni F, Sawyer HR \& Nett TM 1986 Role of luteinizing hormone in regulating luteal function in ruminants. Journal of Animal Science 62 (Suppl 2) 1-13.

O'Shea JD, Rodgers RJ \& Wright PJ 1984 Morphometric analysis and function in vivo and in vitro of corpora lutea from ewes treated with LHRH during seasonal anoestrus. Journal of Reproduction and Fertility 72 75-85.

Rahmanian MS \& Murdoch WJ 1987 Function of ovine corpora lutea after administration of luteinizing hormone-releasing hormone. Journal of Animal Science 64 648-655.

Rodgers RJ, O'Shea JD \& Bruce NW 1984 Morphometric analysis of the cellular composition of the ovine corpus luteum. Journal of Anatomy 138 757-769.

Sasser RG, Niswender GD \& Nett TM 1977 Failure of LH and/or prolactin to prevent PGF 2alpha-induced luteolysis of ovine corpora lutea. Prostaglandins 13 1201-1208.

Scaramuzzi RJ \& Baird DT 1977 Pulsatile release of luteinizing hormone and the secretion of ovarian steroids in sheep during anoestrus. Endocrinology 101 1801-1806.

Schams D \& Berisha B 2004 Regulation of the corpus luteum in cattle - an overview. Reproduction in Domestic Animals 39 $241-251$.

Southee JA, Hunter MG \& Haresign W 1988a Function of abnormal corpora lutea in vivo after GnRH-induced ovulation in the anoestrous ewe. Journal of Reproduction and Fertility 84 131-137.

Southee JA, Hunter MG, Law AS \& Haresign W 1988b Effect of hysterectomy on the short life-cycle corpus luteum produced after $\mathrm{GnRH}$-induced ovulation in the anoestrous ewe. Journal of Reproduction and Fertility 84 149-155.

Tamanini C \& De Ambrogi M 2004 Angiogenesis in developing follicle and corpus luteum. Reproduction in Domestic Animals 39 206-216.

Ungerfeld R, Suarez G, Carbajal B, Silva L, Laca M, Forsberg M \& Rubianes E 2003 Medroxyprogesterone priming and response to the ram effect in Corriedale ewes during the nonbreeding season. Theriogenology $6035-45$.

Weibel ER 1989 Measuring through the microscope: development and evolution of stereological methods. Journal of Microscopy 155 393-403.

White LM, Keisler DH, Dailey RA \& Inskeep EK 1987 Characterization of ovine follicles destined to form subfunctional corpora lutea. Journal of Animal Science 65 1595-1601.

Wright PJ, Geytenbeek PE, Clarke IJ \& Findlay JK 1983 LH release and luteal function in post-partum acyclic ewes after the pulsatile administration of LHRH. Journal of Reproduction and Fertility $\mathbf{6 7}$ 257-262.

Wright PJ, Geytenbeek PE, Clarke IJ \& Findlay JK 1984 Induction of plasma LH surges and normal luteal function in acyclic postpartum ewes by the pulsatile administration of LH-RH. Journal of Reproduction and Fertility 71 1-6.

Xiao E, Xia-Zhang L \& Ferin M 2002 Inadequate luteal function is the initial clinical cyclic defect in a 12-day stress model that includes a psychogenic component in the Rhesus monkey. Journal of Clinical Endocrinology and Metabolism 87 2232-2237.

Received 15 June 2004

First decision 20 July 2004

Revised manuscript received 7 September 2004

Accepted 20 September 2004 